\title{
Pensar e Fazer Justiça: a administração alternati- va de conflitos no Brasil
}

\author{
Moema Dutra Freire Prudente \\ Orientador: Arthur Trindade Maranhão Costa \\ Tese de Doutorado \\ Data da defesa: 27.04.2012
}

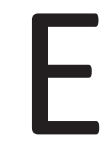

sta tese tem como objeto de estudo o processo de reestruturação do campo de gestão de conflitos interpessoais no Brasil. A seleção e o recorte desse objeto foram motivados pela constatação da grande disseminação de práticas alternativas de gestão de conflitos ocorrida no Brasil, nos últimos anos. E o questionamento quanto aos efeitos dessa disseminação no processo de mudança do campo, por sua vez, orientou os rumos da pesquisa.

Nesse sentido, este trabalho tem como objetivos: (i) caracterizar o campo de gestão de conflitos no Brasil, incluindo a identificação das práticas alternativas nele existentes e sua relação com as práticas tradicionais; (ii) analisar a interação entre os atores presentes no campo, compreendendo a dinâmica das lutas e de cooperação existentes; (iii) investigar influências de outros campos na dinâmica do campo em questão; (iv) e, por fim, a partir das análises anteriores, examinar o processo de mudança no campo de gestão de conflitos no Brasil e sua relação com a de Reforma da Justiça no país. Os conceitos de campo e de habitus de Bourdieu figuram dentre os elementos que dão base à perspectiva teórica desse estudo. A abordagem de análise de redes sociais, por sua vez, ampara metodologicamente o exame do processo de interação entre atores no interior do campo.

Os achados de pesquisa conduzem a conclusões importantes, dentre as quais se destacam: (i) o ingresso das práticas alternativas no Brasil trouxe significativas mudanças para o campo de gestão de conflitos interpessoais. Essas mudanças dizem respeito à introdução de novos atores, o que alterou a dinâmica de poder anteriormente estabelecida; (ii) o Poder Executivo Federal é protagonista na disseminação das práticas alternativas no país e tanto sua presença, como a ampliação de sua atuação no campo são legitimadas pelo discurso das práticas alternativas; (iii) a ideologia das práticas alternativas já está amplamente disseminada no campo de gestão de conflitos, mas essa disseminação restringe-se à esfera discursiva: a implementação das práticas designadas como alternativas ainda reproduz características próprias de uma perspectiva tradicional de 
gestão de conflitos. (iv) E, finalmente, o estudo permite concluir que - diferentemente do observado no contexto internacional - as mudanças do campo de gestão de conflitos no Brasil receberam influência de dinâmicas próprias de outros campos, notadamente do campo político e do campo da segurança pública.

Palavras-chave: Acesso à Justiça, Resolução Alternativa de Conflitos, Reforma da Justiça. 